\title{
多様な設計水準に対応する文章の読みやすさ推定法 PREDICTION METHOD FOR READABILITY OF DOCUMENTS CORRESPONDING TO VARIOUS DESIGN LEVELS
}

\author{
原 直 也 ${ }^{* 1}$, 佐 藤 隆二*2 \\ Naoya HARA and Ryuji SATOH
}

\begin{abstract}
In this paper, in order to construct a design method that can reflect the target level of readability and the evaluation probability, the method of predicting the readability based on the logistic regression that regress the relationship between the three visual factors and the readability of documents is presented.

For the formulation of that relationship, the regression model is chosen, in which the regression coefficient is determined for each different boundary of adjacent category and for each different range of adaptation luminance. The relationship between three visual factors and readability predicted by this chosen model is shown.
\end{abstract}

Keywords : Readability, Design level, Logistic regression, Three visual factors, Equi-readability surface 読みやすさ, 設計水準, ロジステイック回帰, 明視三要素, 等読みやすさ曲面

\section{1.はじめに}

既報 ${ }^{1)}$ で記したように、不特定多数の人が利用する場の環境を利 用者の評価に基づいて設計する際には、多数の人の評価判断基準の ばらつきや、設計時に想定する母集団の属性などを反映した計画が 必要である。多人数の在室者を対象とする室の視環境設計において は評価水準（視対象の読みや寸さの程度など）だけではなく、その 評価水準が達成される確率である評価確率をも併せて設計水準とし て導入し、設計に自由度を与えることが必要と考える。

既報 ${ }^{1)}$ では、観察者の視野内の輝度が均一で変動のない条件下で の無彩色視対象の明視三要素と設計水準（評価水準 : 目標と寸る文 章の読みやすさ、及び、評価確率）との対応関係を、主観評価実験 の結果から明らかにし、その関係を視環境設計に適用可能とする資 料して等読みやすさ曲面が提示された。提示された等読みやすさ曲 面は表、又は、図により提示されており、明視三要素から読みや寸 さの程度を、あるいは、設計水準の読みや寸さからその実現に必要 な明視三要素条件を、それらから読み取る作業が必要で、多大な困 難を伴う。等読みやすさ曲面が示す明視三要素条件と設計水準との 関係が定式化されれば、明視性に基づいた視環境設計がより容易と

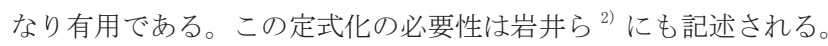

明視要素と読みやすさとの関係を表す式としては、かつて J I S 照 度基準の解説 ${ }^{3)}$ に記載されていた、印東ら ${ }^{4)}$ の実験に基づく河合ら 5) の式があるが、「(文字の) 大きさの知覚には恒常性があるとして、 文字の大きさを視覚で整理統合していないことなどの」問題点は岩 井ら ${ }^{2)}$ が指摘している通りである。

岩井ら ${ }^{2)}$ は、「視認性を定量的に扱うためには、閾上レベルの視
覚特性である非線形を加味する必要があること」の妥当性を検討す る一環として、既報 ${ }^{1)}$ の実験で得られたデータを基に、明視要素と 読みや寸さとの関係を示寸読みや寸さ評価関数を示すが, 評価確率 $50 \%$ に対応した式しか示しておらず、評価確率を設計水準として設 定することは未だ困難である。なお、岩井ら ${ }^{1)}$ に提供した 50 パーセ ンタイル值は、集計対象母集団が既報 ${ }^{1)}$ とは若干異なるために既報 の表の值とは若干異なるものの、その值は酷似している。なお、既 報 ${ }^{1)}$ の実験結果と類似研究との比較は岩井ら ${ }^{2)}$ によって報告されて いる。本稿では、設計水準として評価水準と評価確率とを反映可能 な設計用資料を構築するために、既報の実験結果に基づいて、明視 三要素条件と文章の読みやすさとの関係を、ロジスティック回帰し、 その回帰係数に基づき読みやすさを推定する方法を示す。この方法 により、20,50, 80\%以外の評価確率についても、各評価水準と明視 三要素条件との対応関係が予測可能となる。

\section{2. 明視三要素と読みやすさとの関係の定式化の概要}

ロジステイック回帰はある条件を充たすか否かの確率の対数オッ ズの一般化線形回帰モデルである。本稿では、既報の評定尺度を用 いた読みや寸さの主観評価実験の結果に基づいて、読みやすさがあ る隣接カテゴリー境界未満となる確率を目的変数、明視三要素を説 明変数とした線形回帰モデルにより、読みやすさの関係を回帰する。 その回帰により推定可能となる隣接カテゴリー境界未満となる確率 から、読みやすさの尺度を構成する手法を導入して、明視三要素と 読みやすさとの関係を定式化する方法を提案する。既報 ${ }^{1)} の$ 実験デー タとそのデータを手動回帰した読みやすさと、三種の線形回帰モデ
$* 1$ 関西大学環境都市工学部建築学科 教授 $\cdot$ 博士 $($ 工学 $)$

*2 工博
Prof., Dept. of Arch., Faculty of Environmental and Urban Eng., Kansai Univ., Ph.D. in Eng. Dr.Eng: 
ルにより推定される読みや寸さとの整合性から、その関係の定式化 に適した線形回帰モデルを選択し、明視三要素から推定した読みや すさと明視三要素との関係を示し、視環境設計に有用な読みやすさ 推定式を明らかにする。

\section{3. 主観評価実験の読みやすさの尺度構成と手動回帰}

既報 ${ }^{1)}$ においては順応輝度 L : 15, 50, 200, 600, $1500\left[\mathrm{~cd} / \mathrm{m}^{2}\right]$ 、輝度 対比 C: $0.2,0.29,0.49,0.73,0.92$ 、文字の視角 $\alpha: 7.2,10.9,16.9,25$ .3, 38. 6, 57.9['] の組合せ条件について、文章の読みやすさを 6 段 階の順序尺度カテゴリー（読めない、やっと読める、多少読みにく いが読める、苦労せずに読める、読みやすい、非常に読みやすい) で判定させる主観評価実験を実施した。主観評価実験で得られた特 定条件の読みや寸さに対し、Fig.1 1 示寸ように、隣接カテゴリー 境界ごとに、その境界末満となる相対度数 $\mathrm{p} （$ 図中の）を算出し、 その值に基づいて読みやすさのパーセンタイル值（以下、\%值）を 算定した。既報 ${ }^{1)}$ では\%值と順応輝度 $\mathrm{L}\left[\mathrm{cd} / \mathrm{m}^{2}\right]$ 、輝度対比 C、文字 の視角 $\alpha\left[{ }^{\prime}\right]$ のそれぞれの対数值との関係を、「全ての関係を踏まえ た上で, それらの関係が全体に渡って円滑となるようバランスを採 り」、「明視三要素と読みやすさとの関係を充分に代表」させ手動回 帰した読みや寸さの％值を表に示した。この手動回帰した読みやす さの 50\%值に基づいて評価確率 50\%の、20\%值に基づいて評価確率 $80 \%$ の明視三要素条件を示す等読みやすさ曲面を示した。既報 ${ }^{1)}$ に 提示された等読みやすさ曲面は、その直交空間内に示した、ある評 価確率での評価カテゴリーの境界となる曲面である。

\section{4. 主観評価実験結果のロジスティック回帰}

本稿では、既報 ${ }^{1)}$ で得られた順序尺度カテゴリーの隣接カテゴリー 境界ごとのその境界末満の評価が得られる相対度数 $\mathrm{p}$ の対数オッズ

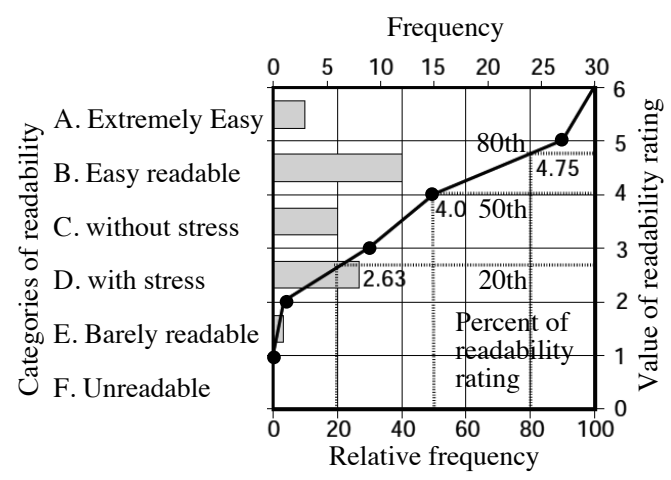

Fig.1 Relationship between categories of readabilty and value of readability rating in calculating method of percentile value of readability rating
を目的变数とし、順応輝度 $\mathrm{L}\left[\mathrm{cd} / \mathrm{m}^{2}\right]$ 、輝度対比 C、文字の視角 $\alpha$ [ $\left.{ }^{\circ}\right]$ のそれぞれの対数值を説明変数としたロジスティック回帰により明 視三要素条件と設計水準との関係を定式化した。相対度数 $\mathrm{p}$ と対数 オッズとの関係は次式となる。

$$
\log O_{z}=\log _{e} \frac{p}{1-p}
$$

本稿では SPSS ver. 25 の二項ロジスティックによる解析機能を利 用し、次式の一次多項式の係数 $a_{\mathrm{L}}, a_{C}, a_{a}, a_{0}$ を推定した。

$$
\log O_{z}=a_{L} \log L+a_{C} \log C+a_{\alpha} \log \alpha+a_{0}
$$

ロジスティック回帰により得られる評価水準毎の係数を用いた回 帰式 (2) は、明視三要素の指標となる順応輝度 L、輝度対比 C、文字 の視角 $\alpha$ の、それぞれの対数を軸とした直交空間における、隣接力 テゴリー境界末満となる確率が $\mathrm{p}$ となる平面を示す。等読みやすさ 曲面が曲面として表現していた明視三要素条件と設計水準との関係 を、ロジスティック回帰では平面として表現することになる。曲面 の方がそれらの関係を柔軟に表現可能であるが、回帰領域を限定す るなど、平面として回帰可能な領域とすれば、ロジスティック回帰 による評価值の推定精度は高くなると考えられる。

ロジスティック回帰において式 (2) の定数項 $a_{0}$ の值を隣接カテゴ リ一境界ごとに推定し係数 $a_{L}, a_{C}, a_{\alpha}$ を全ての隣接カテゴリー境界に ついて共通の值とした「共通推定」と、異なる隣接カテゴリー境界 についてそれぞれ異なる一次多項式の係数を推定した「境界別推定」、 さらに順応輝度領域を 15-50, 50-200, 200-600, 600-1500 [cd/ $\left.\mathrm{m}^{2}\right]$ に分 けた 4 領域別に係数を推定した「順応輝度別推定」の三種の回帰係 数の推定結果を Table1 に示す。

「共通推定」と「境界別推定」では、推定された回帰係数を式 (2) に代入し対数オッズを算出した。「順応輝度別推定」では、まず、観 察時の輝度対比と文字の視角において順応輝度がその領域境界であ る 15, 50, 200, 600, 1500[cd/ $\left.\mathrm{m}^{2}\right]$ の対数オッズをTable 1 の順応輝度 領域ごとの回帰係数を用いた式 (2) で算出した。二つの順応輝度領 域に含まれる順応輝度境界 50, 200, 600 に対して算出された対数オッ ズは、二つの順応輝度領域それぞれで算出した対数オッズの平均を 採り、順応輝度境界と対数オッズの関係（後述、Fig. 2 中の実線）を 得た。観察時の順応輝度に対する対数オッズはこの関係を線形補間 し算出した。

既報 ${ }^{1)}$ においては、カテゴリー境界と、確率 $\mathrm{p}$ ごとに、順応輝度、 輝度対比、文字の視角の関係が、それらの対数の直交座標空間内に

\begin{tabular}{|c|c|c|c|c|c|c|c|c|c|c|c|c|c|c|c|c|c|c|c|c|c|c|c|c|}
\hline & \multirow{3}{*}{\multicolumn{4}{|c|}{\begin{tabular}{|c|}
$\begin{array}{l}\text { Common coefficient } \\
\text { for category boundary }\end{array}$ \\
Range of adaptation luminance \\
$15-1500$
\end{tabular}}} & \multirow{3}{*}{\multicolumn{4}{|c|}{\begin{tabular}{|l}
$\begin{array}{l}\text { Different coefficients } \\
\text { for each category boundary }\end{array}$ \\
Range of adaptation luminance \\
$15-1500$
\end{tabular}}} & \multicolumn{16}{|c|}{$\begin{array}{l}\text { Different coefficients } \\
\text { for each combination of category boundary and range of adaptation luminance }\end{array}$} \\
\hline & & & & & & & & & \multicolumn{16}{|c|}{ Range of adaptation luminance } \\
\hline & & & & & & & & & \multicolumn{4}{|c|}{$15-50$} & \multicolumn{4}{|c|}{$50-200$} & \multicolumn{4}{|c|}{$200-600$} & \multicolumn{4}{|c|}{$600-1500$} \\
\hline & $a_{L}$ & $a_{C}$ & $a_{a}$ & $a_{0}$ & $a_{L}$ & $a_{C}$ & $a_{a}$ & $a_{0}$ & $a_{L}$ & $a_{C}$ & $a_{a}$ & $a_{0}$ & $a_{L}$ & $a_{C}$ & $a_{a}$ & $a_{0}$ & $a_{L}$ & $a_{C}$ & $a_{a}$ & $a_{0}$ & $a_{L}$ & $a_{C}$ & $a_{a}$ & $a_{0}$ \\
\hline \begin{tabular}{l|l}
$\cong$ & 1 \\
\multirow{2}{*}{} &
\end{tabular} & & & & 16.132 & -2.025 & -8.231 & -20.805 & 22.090 & -3.015 & -9.047 & -20.903 & 23.379 & -2.305 & -9.045 & -22.694 & 23.996 & -1.843 & -8.404 & -23.344 & 23.771 & -0.762 & -7.954 & -22.183 & 19.840 \\
\hline 2 & & & & 18.237 & -2.065 & -8.324 & -19.557 & 23.424 & -2.456 & -7.638 & -15.422 & 19.310 & -2.071 & -7.831 & -19.521 & 23.309 & -2.091 & -9.199 & -24.938 & 28.812 & -2.221 & -11.857 & -30.463 & 34.088 \\
\hline 3 & -1.570 & -8.058 & -15.804 & 20.892 & -1.565 & -8.461 & -14.874 & 19.553 & -2.891 & -9.662 & -14.212 & 20.229 & -2.209 & -9.766 & -17.118 & 22.859 & -1.140 & -8.224 & -17.057 & 20.864 & 0.356 & -8.032 & -16.537 & 16.148 \\
\hline 4 & & & & 23.995 & -1.298 & -8.389 & -13.401 & 19.758 & -1.718 & -7.873 & -12.398 & 19.036 & -1.397 & -8.570 & -13.659 & 20.148 & -1.311 & -8.675 & -14.362 & 20.933 & -0.516 & -9.011 & -14.117 & 18.264 \\
\hline 5 & & & & 27.382 & -1.345 & -8.131 & -16.238 & 27.545 & -1.652 & -7.496 & -15.134 & 26.356 & -1.443 & -7.761 & -16.569 & 28.307 & -1.673 & -8.587 & -18.037 & 30.981 & -0.218 & -8.862 & -16.713 & 24.726 \\
\hline
\end{tabular}

Table1 Coefficients of logistic regression analysis 
等読みやすさ曲面として示されたが、式 (2) においてある確率 $\mathrm{p}$ 、す なわちある対数オッズを与えると、式はその直交座標空間内の平面 を示すことから、それらの関係を平面とした回帰となる。「共通推定」 では直交座標空間内における異るカテゴリー境界面は一平面の平行 移動での回帰となり、「境界別推定」では異るカテゴリー境界面はそ れぞれ異なる傾きの平面による回帰となる。「順応輝度別推定」では、 カテゴリー境界面は順応輝度領域別の異る平面による回帰となる。

対数オッズと順応輝度との関係を Fig. 2 で、輝度対比との関係を Fig. 3 で、文字の視角との関係をFig. 4 で、それぞれ視環境設計時に 多用されると考えられるカテゴリー境界（3：多少読みにくいが読め る-苦労せずに読めるの境界, 4 : 苦労せずに読める-読みやすいの 境界）ごとに、一般的な設計対象環境に近い順応輝度や文字の視角 における関係を選定して例示寸る。図中の記号は既報 ${ }^{1)}$ の実験結果

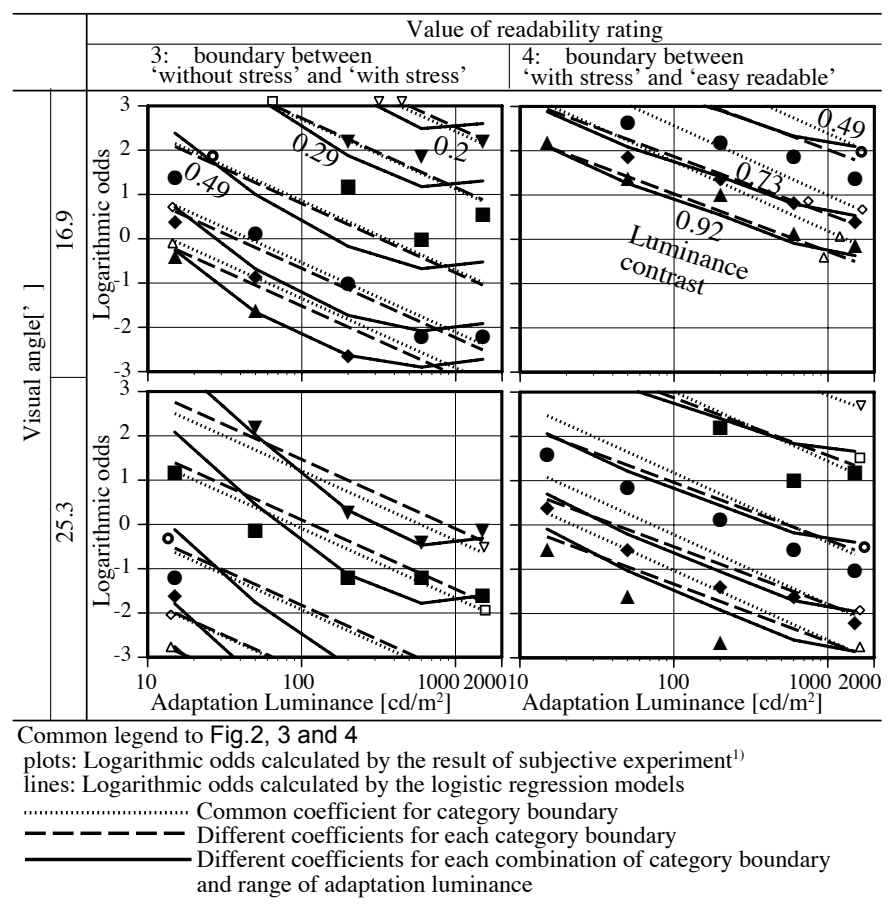

Fig.2 Relationship between adaptation luminance and logarithmic odds

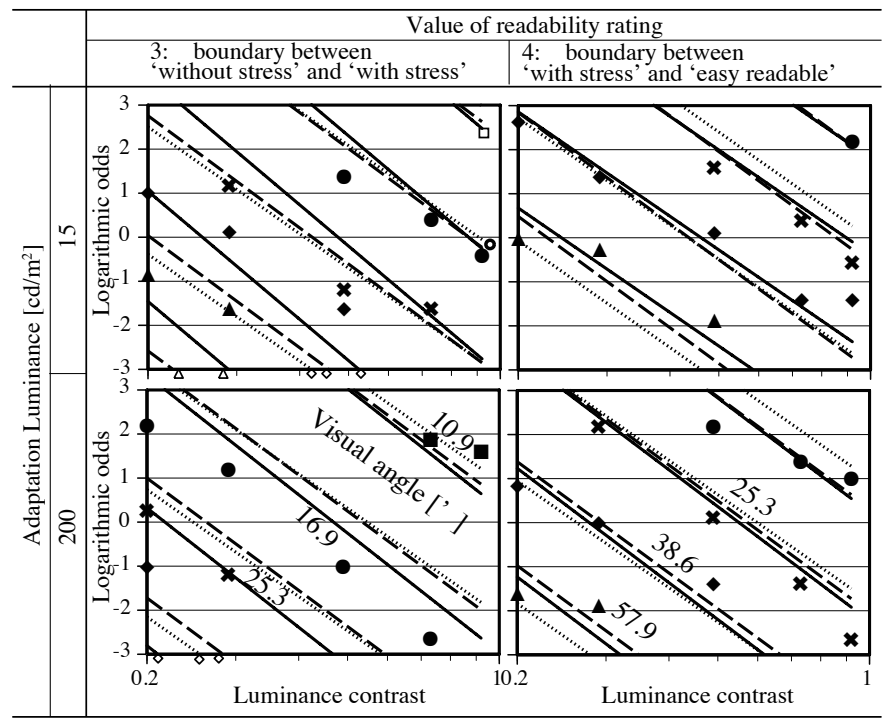

Fig.3 Relationship between luminance contrast and logarithmic odds
から得られた対数オッズで、ロジスティック回帰の「共通推定」「境 界別推定」、「順応輝度別推定」による対数オッズの回帰線をそれぞ れ点線、破線、実線で示す。それら回帰線は実験結果の対数オッズ と同じく、およそ背景輝度が高く、輝度対比が高く、文字の視角が 高く、カテゴリー境界が低いほど低い対数オッズとなり、実験結果 を反映している。「共通推定」では、カテゴリー境界に共通して係数 $a_{L}, a_{C}, a_{a}$ が推定されるため点線の傾きは全て等しい。「境界別推定」「順 応輝度別推定」では、その係数がカテゴリー境界別に推定されるため、 破線や実線の傾きは同じカテゴリー境界 (「順応輝度別推定」はさら に順応輝度領域別）で等しいが境界が異なれば傾きは異なる。

順応輝度と対数オッズとの関係（Fig. 2) において、同一輝度対比 (図中同一記号) の実験データの連なりは、順応輝度の低い領域にお いてはカテゴリー境界 4 の方の傾きが緩やかである。「共通推定」で は、この傾向を反映した回帰ができないが、「境界別推定」では、係 数 $a_{L}$ がカテゴリー境界別に推定されるためその傾向が反映され、波 線の傾きは、カテゴリ一境界 4 の方が緩やかになる。一方、カテゴリー 境界 3 では順応輝度が低いと記号の連なりの傾きは急となり、高い ほど緩やかになり、負から正と逆転する。「共通推定」「境界別推定」 は、順応輝度領域に関わらず共通した係数 $a_{L}$ を推定するため、この 順応輝度による傾きの変化を反映出来ない。「順応輝度別推定」はこ の順応輝度による傾きの変化を回帰するために順応輝度領域別に回 帰係数を推定し、図中実線は直線ではなく折線で回帰され、この傾 きの変化をある程度反映している。

輝度対比と対数オッズとの関係（Fig. 3）において、「共通推定」「境 界別推定」「順応輝度別推定」で回帰された点線、破線と実線、および、 同一視角（図中同一記号）の実験データの連なりも含め、カテゴリー 境界、順応輝度や視角によってその傾きに大差はなく、回帰線は実 験データのもつ傾向を反映している。

文字の視角と対数オッズとの関係（Fig. 4）において、「共通推定」、 「境界別推定」「順応輝度別推定」で回帰された点線、破線と実線、 および、同一視角（図中同一記号）の実験データの連なりも含め、カ テゴリー境界、順応輝度や輝度対比によってその傾きに大差はなく、 回帰線は実験データのもつ傾向を反映している。

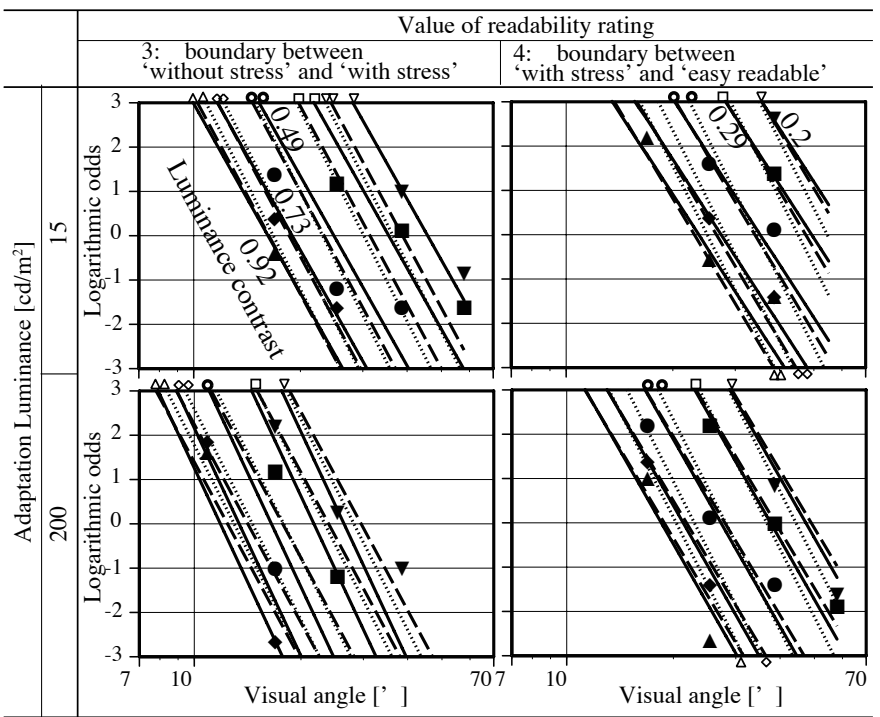

Fig.4 Relationship between visual angle and logarithmic odds 
a) Relation to percentile value of experimental result
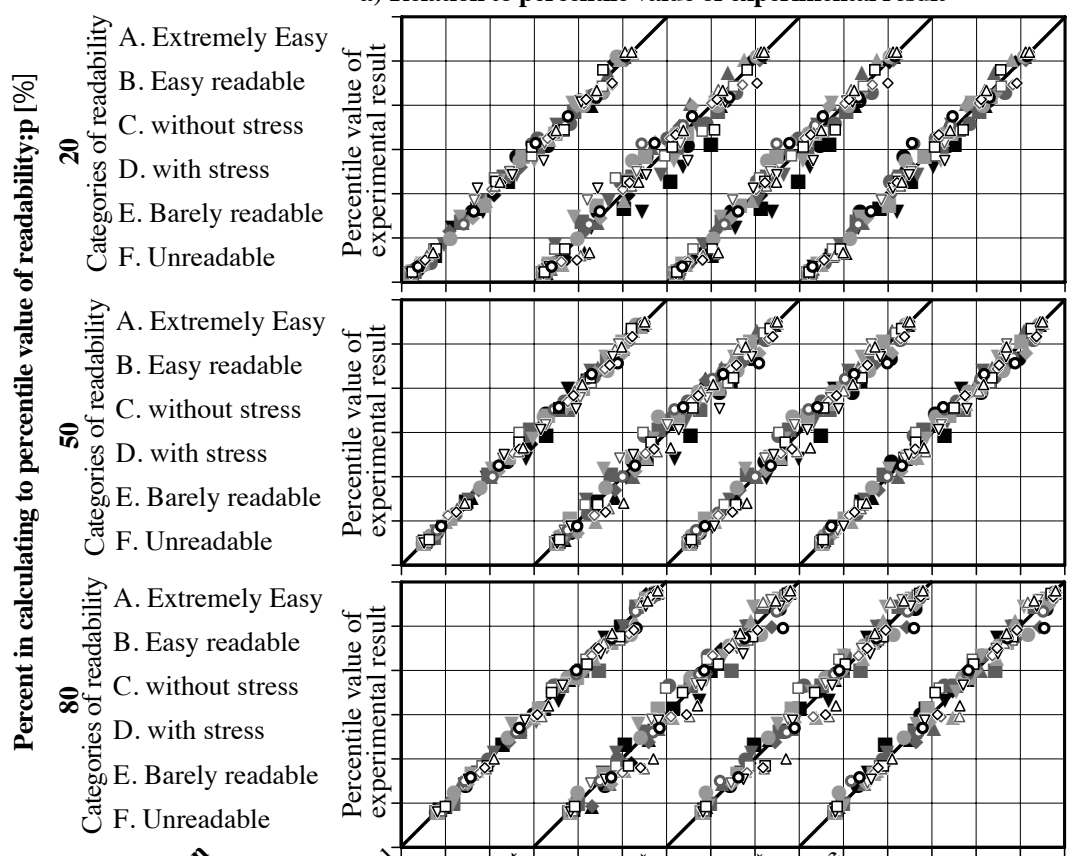

b) Relation to percentile value of manual regression
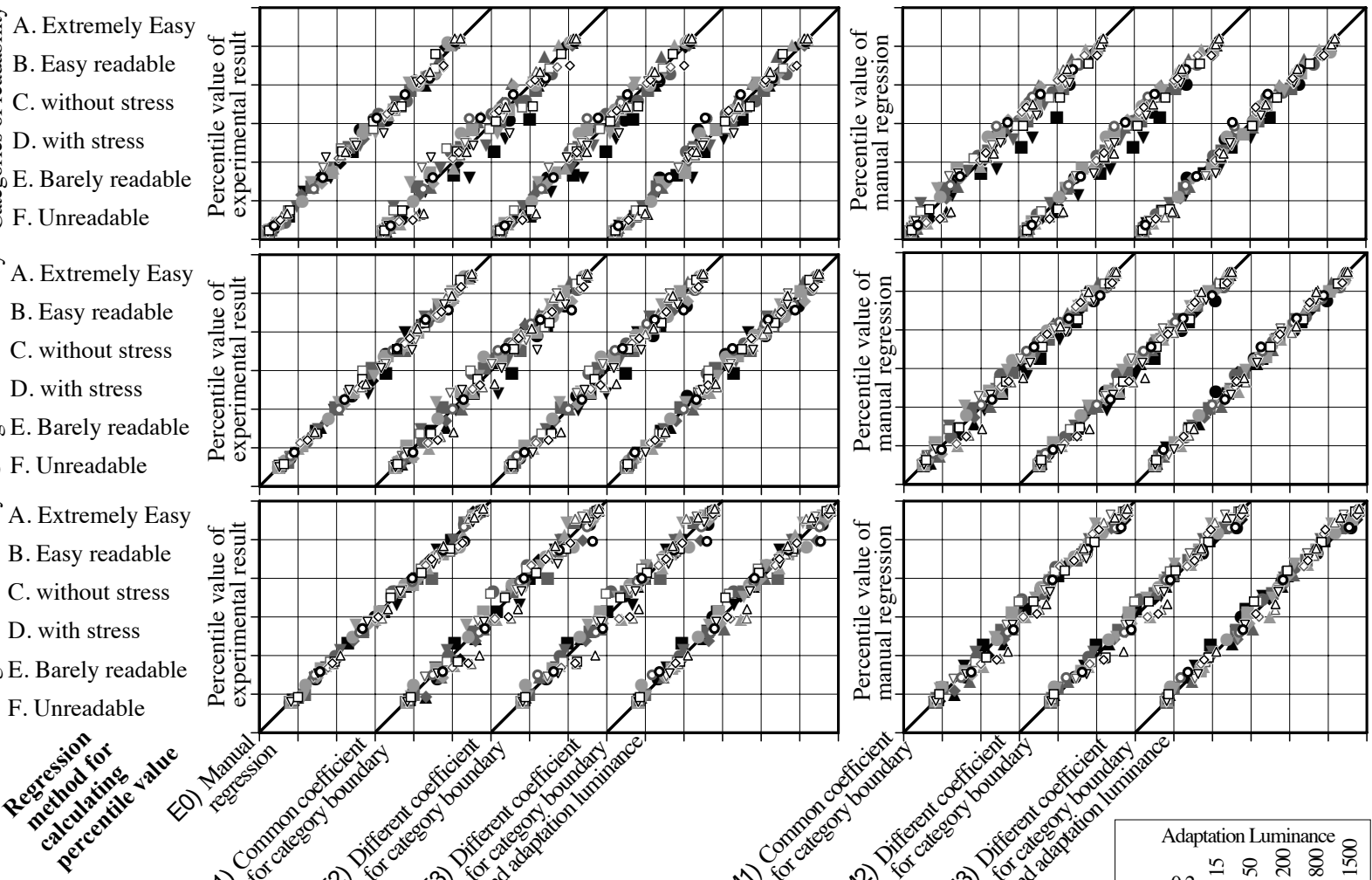

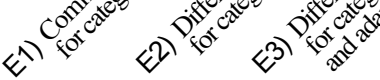
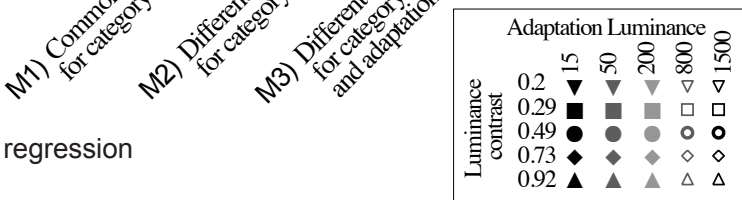

Fig.5 Relationship between percentile value of manual regression or logistic regression and that of experimental result or manual regression

この確率 p は、Fig. 1 における隣接カテゴリー境界の累積相対度数(図

中○）に対応する值である。主観評価実験の結果から累積度数分布

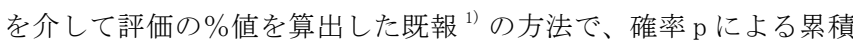
相対度数を設計目標とする評価確率などに対応したパーセントで線 形補間して読みやすさの\%值が算出される。

既報 ${ }^{1)}$ における手動回帰、本稿で示した「共通推定」、境界別推定」、 「順応輝度別推定」のロジスティック回帰による読みやすさ％值と、 既報実験結果で得られた読みやすさ\%值との関係を Fig. 5 a) に、ロ ジスティック回帰による読みやすさ\%值と既報における手動回帰に よる読みやすさ\%值との関係を Fig. 5 b) に示し、それら回帰による 予測誤差を Tab1e2 に示す。図中の傾き 1 の直線は、比較対象の\%值 と、回帰による\%值が等しくなる位置であり、図中記号が直線上に 集中するほど比較対象に対する整合性は高い。また、予測誤差 $\delta$ は 比較対象とする\%值 $R_{r i}$ 、回帰による \%值 $R_{e i}$ とし、明視三要素の組 み合わせ条件 $\mathrm{i}$ の全ての条件数 $\mathrm{n}$ を用いて次式で算出した值である。

$$
\delta=\sqrt{\frac{\sum_{i=1}^{n}\left(\mathrm{R}_{r i}-\mathrm{R}_{e i}\right)^{2}}{n}}
$$

実験データの\%值に対する、既報 ${ }^{1)}$ の手動回帰による\%值との関 係（Fig. 5 E0）は図中記号が直線上に集っており比較的整合性が高 く予測誤差は最も小さい。「共通推定」による\%值との関係（Fig. 5 E1）では記号は直線から離れるものもあり予測誤差が最も大きく整 合性は低く、「境界別推定」による\%值との関係（Fig. 5 E2）、「順応 輝度別推定」による\%值との関係（Fig. 5 E3）と回帰係数が多い手法 
ほど図中記号が直線上に集まり予測誤差も順に小さくなり整合性は 高い。しかし、実験データの\%值は、既報 ${ }^{1)}$ でもその傾向を代表す る手動回帰を施したように、必ずしも明視三要素と評価との関係を 的確に表現していない。手動回帰による\%值は、明視三要素と読み や寸さ\%值との「全ての関係を踏まえた上で, それらの関係が全体 に渡って円滑となるようバランスを採り」、「明視三要素と読みや寸 さとの関係を充分に代表」させており、手動回帰による\%值に対す るロジステイック回帰による％值の整合性が高い方が回帰方法の妥 当性が高いと考えられる。手動回帰による\%值に対する、「共通推定」 による\%值との関係（Fig. 5 M1）では記号は直線から離れるものもあ り予測誤差が最も大きく整合性は低く、「境界別推定」の\%值との関 係（Fig. 5 M2）、「順応輝度別推定」の\%值との関係（Fig. 5 M3）と回 帰係数が多い手法ほど予測誤差も順に小さくなり整合性は高い。

Table2 右最下欄の手動回帰による\%值に対する「順応輝度別推定」

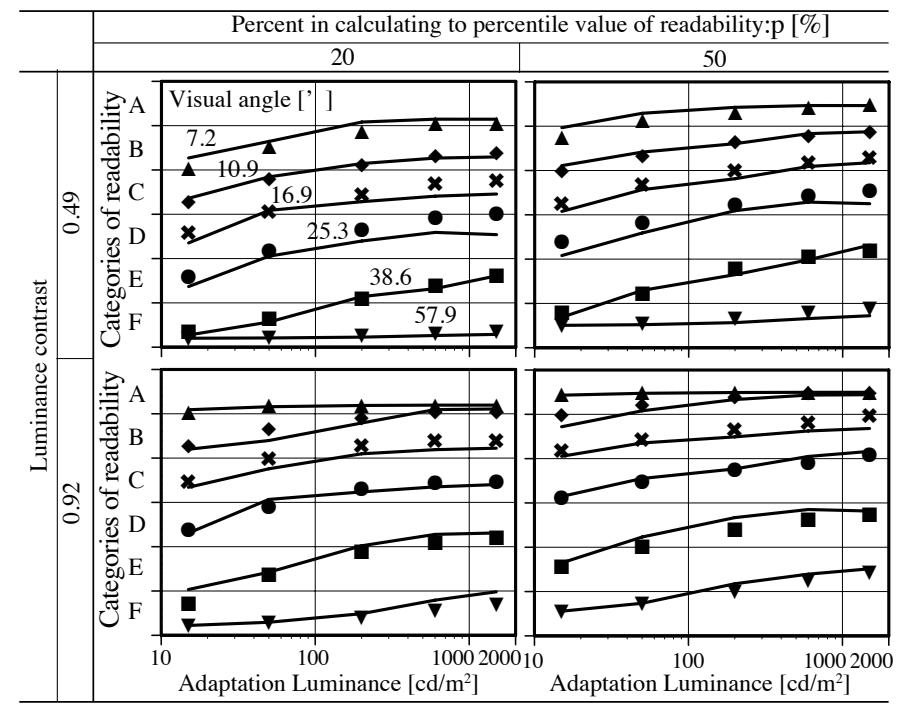

Common legend to Fig.6, 7 and 8

plots: manual regression data

lines: logistic regression data by different coefficients for each combination of category boundary and range of adaptation luminance)

Fig.6 Relationship between adaptation luminance and percentile value of readability

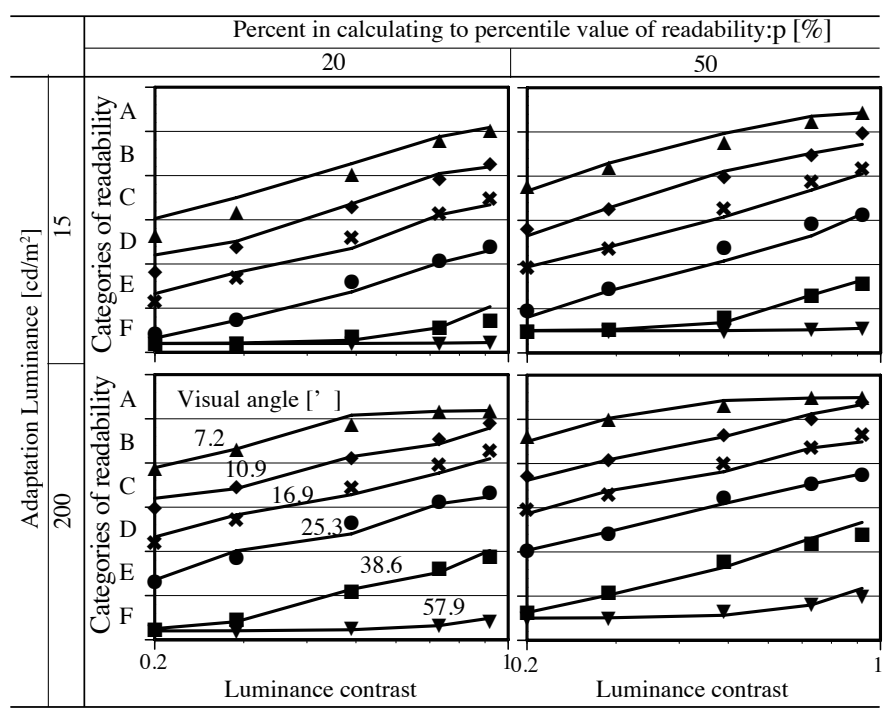

Fig.7 Relationship between luminance contrast and percentile value of readability
の予測誤差は、同表最上段の実験データの\%值に対する手動回帰の 予測誤差に近い值となり、主観評価実験の結果を系統的に表現する 際の誤差としては許容できる值と考える。対数オッズを完全な平面 で回帰した「共通推定」や「境界別推定」による予測誤差は、評価 確率 $80 \%$ に対応する $20 \%$ 值で比較的誤差が大きい。ロジステイック 回帰の「順応輝度別推定」による\%值が、実験データの％值と手動 回帰による\%值の両方に対する整合性が高く、本稿では「順応輝度 別推定」による回帰が妥当と判断する。

\section{6. 明視三要素と視環境設計時の設計水準との関係}

明視三要素と「順応輝度別推定」による読みやすさ\%值、およ び、既報 ${ }^{1)}$ の手動回帰による\%值との関係を、順応輝度との関係を Fig. 6、輝度対比との関係を Fig. 7、文字の視角との関係を Fig. 8 に 例示する。図中実線が「順応輝度別推定」による読みやすさ％值、 記号が既報の手動回帰による\%值を示す。手動回帰によって隣接条 件の傾向を反映し明視三要素全てに対して自然な連なりを持つ記号 に比べて、実線は一部に隣接条件の傾向を反映せず不自然な連なり が散見されるものの、いずれの関係においても「順応輝度別推定」 による読みやすさ\%值が、およそ手動回帰による\%值が持つ傾向を 反映している。

既報 ${ }^{1)}$ に示された手動回帰による明視三要素と読みやすさとの関 係は、本項で導出した「順応輝度別推定」のロジスティック回帰か ら推定されるその関係よりも、より良好に関係を示すものと考えら れるが、その視環境設計一の直接的利用は、用意された条件の固定 された図表からの数值を読みとりという困難を伴う。本稿で示した 「順応輝度別推定」による読夕やすさ％值の推定法を利用すれば、設 計水準（評価水準：目標とする文章の読みや寸さ、及び、評価確率） を任意に設定して、明視三要素と読みや寸さとの関係を容易に得る ことができる。本稿に示した回帰係数とそれを利用した推定の計算 法は、単純ではなく手計算では煩雑なものとなるが、その計算を実 現する読みやすさの\%值を推定する関数は簡単なプログラムで作成 可能である。手動回帰により示された設計資料に対して多少の誤差 と不自然さを伴うものの、視環境設計などへの適用の容易性を考え れば、本稿で示した推定法は非常に有用である。

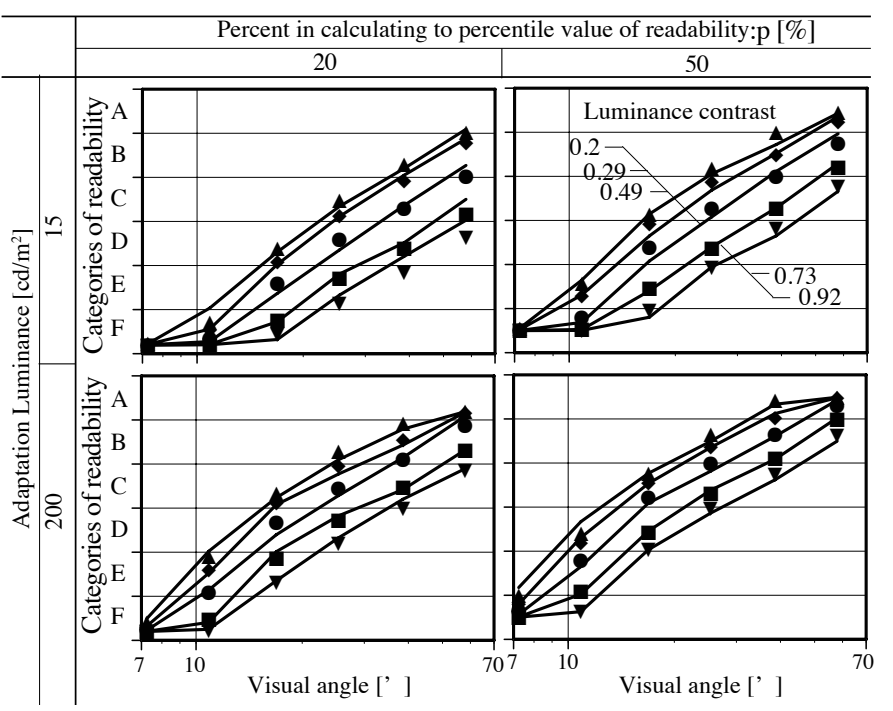

Fig.8 Relationship between visual angle and percentile value of readability 


\section{7. おわりに}

既報 ${ }^{1)}$ に示した等読みやすさ曲面の示す明視要素と設計水準（評 価水準 : 読みやすさ、及び、評価確率）との対応関係をロジスティッ ク回帰を適用して推定する手法を示し、「順応輝度別推定」による回 帰モデルを用いた推定が妥当と判断し、その推定值と既報の手動回 帰による評価の整合性を示した。視環境設計において多様な設計水 準を導入しながら明視性の検討を容易に行うには、本稿に示した推 定法が有用となる。

\section{謝辞}

本稿で報告した内容の大元となる実験結果は、著者が大阪大学在学 時に取り組んだ研究に基づく。ここに記して謝意を表す。

\section{参考文献}

1) Hara, N. and Satoh, R. :' Equi-Readability Surface' of three visual factors corresponding to various design level about readability of documents, Journal of Environmental Engineering (Transactions of AIJ), 575, pp. 15-20, 2004.1 (in Japanese)
原直也，佐藤隆二 : 文章の読みやすさについての多様な設計水準に対応す る明視三要素条件を示す「等読みや寸さ曲面」，日本建築学会環境系論文 集 ，575，pp. 15-20，2004. 1

2) Iwai, W. and Okajima, K. : Visibility Index Functions for positive contrast text, Journal of the Illuminaing Enginering Institute of Japan, 88-11, pp. 874-881, 2004.11 (in Japanese)

岩井彌、岡嶋克典 : 正対比文字で構成された文章に対する読みやすさ評価 関数，照明学会誌，88-11，pp. 874-881，2004.11

3) JIS 29110-1979: Recommended Levels of Illumination, Japanese Industrial Standards, 1979 Jis 29110-1979 : 照度基準，日本工業規格, 1979

4) Indow, T. and Kawai, S. : Phsychological Study on Optimal Levels of Illumination, Journal of the Illuminaing Enginering Institute of Japan, 49-2, pp. 52-63, 1965. 2 (in Japanese)

印東太郎、河合悟 : 適正照度に関する心理学的実験，照明学会雑誌，492, pp. 52-63, 1965. 2

5) Kawai, S. and Krossawa, R. : An Empirical Fomula for the Relation of Readability to Illuminance, Journal of the Illuminaing Enginering Institute of Japan, 57-6, pp. 580-583, 1973.6 (in Japanese) 河合悟、黒沢凉之助 : 照度と読みやすさとの関係を表す簡単な実験式，照 明学会雑誌, 57-6, pp. 580-583, 1973.6 


\title{
PREDICTION METHOD FOR READABILITY OF DOCUMENTS CORRESPONDING TO VARIOUS DESIGN LEVELS
}

\author{
Naoya HARA*1 and Ryuji SATOH*2 \\ ${ }^{* 1}$ Prof., Dept. of Arch., Faculty of Environmental and Urban Eng., Kansai Univ., Ph.D. in Eng.
}

When designing the environment used by an unspecified number of people based on the evaluation of users, it is necessary to plan reflecting the variation of the evaluation criteria of a large number of people and the attributes of the people assumed at designing. In the visual environment design of the room targeting a large number of people, it is necessary to give flexibility to the design by introducing various design levels such as an rating level and an evaluation probability. The rating level is the degree of visibility of the visual target and the evaluation probability is the probability that the rating level is achieved.

In this paper, in order to construct a design method that can reflect the rating level and the evaluation probability as the design level, the method of predicting the readability rating based on the regression coefficient by logistic regression that regress the relationship between the three visual factors and the readability of documents is presented.

Based on the result of the subjective evaluation experiment of readability in the previous report, the relationship between three visual factors and readability is regressed by logistic regression, which is the linear regression model with setting the logarithmic odds of the probability being less than the neighboring boundary of readability category as the objective variable and three visual factors as the explanatory variable. With introducing a method of constructing a readability scale from the probability that can be predicted by the regression, it is proposed to formulate the relationship between three visual factors and readability.

Consistency is examined on readability of the experimental data in the previous report and that obtained by manual regression of that data and that predictted by the three kind of regression models. For the formulation of the relationship between three visual factors and the design level, the regression model is chosen as a most suitable one in which the regression coefficient is determined for each different adjacent category boundary and for each different range of adaptation luminance. The good relationship between three visual factors and readability predicted by this chosen model is shown and a useful readability prediction method for visual environment design is presented in this paper. The prediction method shown in this paper is useful for facilitating examination of visibility while introducing various design levels in visual environment design.

(2019 年 3 月 10 日原稿受理, 2019 年 6 月 12 日採用決定) 